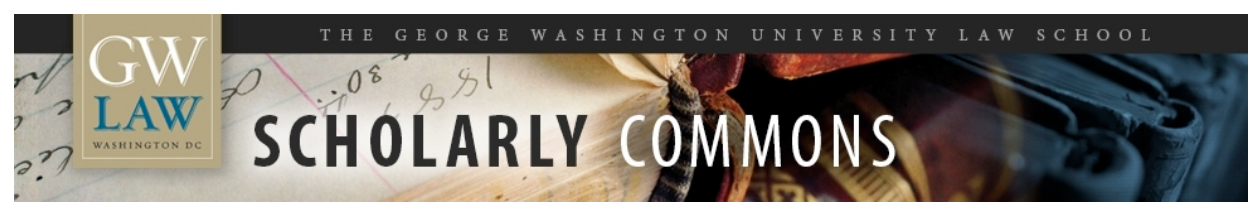

\title{
Incentive Effects from Different Approaches to Holdup Mitigation Surrounding Patent Remedies and Standard-Setting Organizations
}

\author{
F. Scott Kieff \\ George Washington University Law School, skieff@law.gwu.edu \\ Anne Layne-Farrar
}

Follow this and additional works at: https://scholarship.law.gwu.edu/faculty_publications

Part of the Law Commons

\section{Recommended Citation}

F. Scott Kieff and Anne Layne-Farrar, Incentive Effects from Different Approaches to Holdup Mitigation Surrounding Patent Remedies and Standard-Setting Organizations, Journal of Competition Law \& Economics (forthcoming 2013).

This Article is brought to you for free and open access by the Faculty Scholarship at Scholarly Commons. It has been accepted for inclusion in GW Law Faculty Publications \& Other Works by an authorized administrator of Scholarly Commons. For more information, please contact spagel@law.gwu.edu. 


\title{
INCENTIVE EFFECTS FROM DIFFERENT APPROACHES TO HOLDUP MITIGATION SURROUNDING PATENT REMEDIES AND STANDARD-SETTING ORGANIZATIONS
}

\author{
F. Scott Kieff ${ }^{*} \&$ Anne Layne-Farrar ${ }^{\dagger}$
}

\begin{abstract}
Debates about patent policy often focus on the potential for the threat of a court-imposed remedy for patent infringement to cause manufacturing entities and others to suffer patent holdup, especially when standardized industries are involved. This article uses lessons from the broader economics and political science literatures on holdup to explore various approaches to setting remedies for patent infringement - namely injunctions and money damages in the form of lost profits or reasonable royalties - with an eye towards the nature and extent of various forms of holdup they each might generate. In so doing, the article contrasts various narrower sub-categories of the broad holdup problem, including patent holdup, reverse patent holdup, and government holdup. The article elucidates a number of existing legal institutions and organizations that significantly mitigate the threat of patent holdup, including particular doctrines in the law of patent remedies and particular private ordering arrangements such as Standard Setting Organizations (SSOs). It also highlights some of the unfortunate unintended consequences of currently popular suggestions for mitigating patent holdup. It then explores the economic incentives driving the actions by both patent holder and licensee to show different categories of holdup risk they create. It closes by introducing a suggested framework for courts and administrative agencies to use to directly target the identified categories of holdup risk, and thereby limit harmful side effects.
\end{abstract}

JEL: A12, B25, D23, D45, K4, K11, K20, L41, L44, O31, O33, O34

\section{INTRODUCTION}

This article offers a comparative institutional analysis of different approaches to one of today's hot topics in patent law: the ways in which various approaches to setting remedies for patent infringement-namely injunctions, ordinary damages in the form of lost profits or reasonable royalties, and enhanced damages including attorney fees and multipliers of ordinary damagesmay affect the incentives of various participants in the marketplace surrounding patents in ways that increase the risk of various types of holdup to varying degrees. In so doing, it builds on the literature that compares the type of holdup that occurs in the marketplace by private actors asserting property rights (of which patent holdup has become one infamous example) with the type of holdup that occurs by and through government actors implementing the sorts of court and

\footnotetext{
* Fred C. Stevenson Research Professor, George Washington University Law School; Ray \& Louise Knowles Senior Fellow, Stanford University Hoover Institution. Email: skieff@law.gwu.edu.

† Vice President, Charles River Associates. Email: alayne-farrar@crai.com. This work is part of the Hoover Task Force on Property Rights, Freedom, and Prosperity, which studies the philosophical, historical, legal, and economic foundations of property rights, as well as the Hoover Project on Commercializing Innovation, which studies the law, economics, and politics of innovation and which is available online at www.innovation.hoover.org. The opinions in this article are the authors' independent academic views and are not attributable to their organizations or affiliates. The authors gratefully acknowledge substantive contributions from James E. Daily, Stephen H. Haber, J. Gregory Sidak, Daniel F. Spulber, and participants in the Research Roundtable on Technology Standards, Innovation, and Market Coordination held on February 7-8, 2013, at the Searle Center on Law, Regulation, and Economic Growth at the Northwestern University School of Law.
} 
agency reviews suggested by most of the recent high-profile court decisions and agency actions in the field of patents.

In keeping with the diverse uses in the literature of the term holdup, this article uses that term to refer to a broad category of phenomena, which includes various narrower sub-categories such as patent holdup, reverse patent holdup, and government holdup. ${ }^{2}$ While the popular perspective, reflected in most of the recent academic literature and nearly all of the recent high-profile government actions in the field of patents, focuses almost entirely on avoiding the risk of only patent holdup - one of several sub-categories - this article adopts a comparative institutional approach that considers how different legal rules affect incentives in ways that impact the risks of each of these three sub-categories.

For example, the Federal Trade Commission recently issued an extensive report focusing on the purported patent holdup problem in the particular area of patent remedies relating to the standard setting organizations, ${ }^{3}$ and Judge Richard Posner sitting by designation as a trial judge recently issued with much fanfare a decision to dismiss the Apple v. Motorola case before trial because he found that neither side had shown it had suffered any actual harm. ${ }^{4}$ He then blogged about the "dysfunctional patent system" in the U.S. and published a piece in The Atlantic 6 complaining about a host of purported problems in the patent system that the FTC Report and many in the academic literature generally attribute to patent holdup. As detailed by the FTC and others, the crux of the purported patent holdup problem is the effort by patentees to extort too high of a licensing price against the threat of suing a manufacturer of a technology after the manufacturer has sunk the cost of various investments, like building a factory or designing complementary components. ${ }^{7}$ The problem is said to be exacerbated by the prevalence of "low quality" patents: manufacturers see too many of the asserted patents to be worth far less, if not entirely worthless, than claimed by the patentee, usually because non-infringing technologies are economic substitutes or the legal requirements for a valid patent were not met. ${ }^{8}$

This article offers a contrasting view to the one sketched above. While the problems that holdup can create are clear, it is also clear that such problems can emerge from many different quarters and in many different contexts, far beyond the relatively narrow context of patent holders exploiting manufacturers, either within or without the standard-setting context. This article takes a broader view to highlight the need for a carefully balanced approach to finding solutions to the risk of holdup in the context of patents and standard-setting. It points out the broader reach of the holdup problem in economics, of which patent holdup is just one narrow example, to elucidate the

\footnotetext{
${ }^{1}$ See generally Richard A. Epstein, F. Scott Kieff \& Daniel F. Spulber, The FTC, IP, and SSOs: Government Hold-Up Replacing Private Coordination, 8 J. COMPETITION L. \& ECON. 19 (2012) (collecting sources); Anne Layne-Farrar, Gerard Llobet \& A. Jorge Padilla, Payments and Participation: The Incentives to Join Cooperative Standard-Setting Efforts, J. ECON. \& MGT. STRATEGY (forthcoming 2013).

${ }^{2}$ For more on the sub-categories reverse patent holdup and government holdup, see discussions infra, note 18 and Part IV.B (on reverse patent holdup, also called "holdout" and "licensee holdup"), and notes 22-26 and accompanying text (on government holdup).

${ }^{3}$ Fed. Trade Comm'n, The Evolving IP MarketPlace: Aligning Patent Notice and Remedies with Competition 28, 234-35 (2011) [hereinafter "FTC Report"].

${ }^{4}$ Apple, Inc. v. Motorola, Inc., No. 1:11-cv-08540 (N.D. Ill. June 7, 2012).

${ }^{5}$ See, e.g., Richard Posner, Capitalism-Posner, The BeCKer-Posner Blog (June 3, 2012), http://www.becker-posnerblog.com; Richard Posner, Do Patent and Copyright Law Restriction Competition and Creativity Excessively? Posner, THE BECKER-POSNER BLOG (Sept. 30, 2012), http://www.becker-posner-blog.com.

${ }^{6}$ Richard A. Posner, Why There Are Too Many Patents in America, The Atlantic, July 12, 2012. But see Richard A. Epstein, Richard Posner Gets It Wrong, DEFINING IDEAS, July 31, 2012.

${ }^{7}$ See, e.g., FTC Report, supra note 3, at $191 \mathrm{n} .61$ (focusing on sunk costs of the infringer).

${ }^{8}$ See Mark A. Lemley \& Carl Shapiro, Reply: Patent Holdup and Royalty Stacking, 85 TEX. L. REV. 2163 (2007) (arguing that the holdup problem for patents is due to two factors: the large number of patent claims determined to be invalid or non-infringed and the ability for patent infringement remedies to impact non-infringing components of products adjudicated to have infringing components).
} 
nature and function of the risk and various approaches to lessen that risk. In so doing, the article helps targeting the precise mechanisms by which different types of holdup are thought to occur, thereby endeavoring to directly mitigate the problems raised by patent critics while minimizing unintended consequences that would undermine the core goals of the patent system: encouraging risky investments in innovation and its commercialization so as to facilitate coordination among all commercial actors and thereby increase competition and access to patented technologies.

The article proceeds as follows. Part II briefly reviews the well-studied ways in which the broadly defined problem of holdup has been shown throughout extensive practical experience and academic study to have a negative impact, and the ways in which various tools and techniques have been used to mitigate this pernicious effect. Along the way, Part II explores some of the ways in which the broad category of holdup is sometimes observed from the perspective of particular individuals within an economic interaction, who may perceive the other side of holdup's inherently symmetrical nature. The same interaction between counter parties to an economic exchange may be seen by one as posing the risk of holdup and the other as posing the risk of reverse holdup. In addition, whichever party is better able to wield the political influence needed to invoke particular government action may generate a third sub-category of holdup that can be seen as government holdup. Part III reviews the many dimensions of the patent system that do not relate to the rules for court-imposed remedies for infringement and that go a long way towards mitigating several important risks of patent holdup. Part IV outlines the main features of patent remedies under existing law and explores the different key categories of residual risks of patent holdup they do raise, with particular focus on the standard setting context. As part of that analysis, Part IV points out the ways in which contrasting forms of holdup risk can emerge, including, for example, reverse patent holdup. Part V outlines the contrast between the popular suggestions for new rules or regulations to curb patent holdup and our suggested approach towards a framework for mitigating each of the key categories of holdup risks. In so doing, it highlights the ways in which these different approaches interact with the core mechanisms through which each category of holdup is likely to occur. Part VI concludes, pointing out that if our societal goals are to decrease the overall extent of the various forms of holdup risk in markets over patented technologies, increase the overall rate of invention and its commercialization, and increase overall competition as reflected in diversity in firm size and business models among participants in the markets for commercializing innovation, then society should consider moving in a different direction than suggested by current trends in the academic and policy debates about patent remedies.

\section{A BRIEF HISTORY OF HOLDUP AND ITS MITIGATION TECHNIQUES}

The problem of holdup is well studied in the economic history literature and generally refers to the problem that arises out of the interaction between asset specificity and opportunism. Nobel Prizesharing economist Oliver Williamson has long studied transactions and offers a widely accepted definition of these terms. He explains that asset specificity refers to the condition in which an asset cannot be redeployed from its presently intended use to some alternative use without a decline in value. ${ }^{9}$ Imagine finding yourself under the hot sun of the tropics holding a large quantity of some rapidly rotting agricultural produce like bananas or sugar cane, suddenly sad to learn that your best laid plans to sell at the relatively high cash price for fresh harvest are at increasing risk. You

\footnotetext{
${ }^{9}$ Oliver E. Williamson, The ECONOMiC InStitutions OF CAPitalism 52-56 (Free Press 1985) (reviewing literature and explaining that "[a]t least four different types of asset specificity are usefully distinguished: site specificity; physical asset specificity; human asset specificity; and dedicated assets . . . [and that t]he importance of asset specificity to transaction cost economics is difficult to exaggerate").
} 
would have to quickly develop alternative plans for this harvest, like a last-minute rush to find and close a deal with purveyors of compost or manufacturers of distilled spirits already operating, or purporting to operate, at their comfortable capacity and therefore only willing to pay a significantly reduced price for your produce. In this story, the harvested crop in the hands of its seller faces an asset specificity problem because it is specifically adapted for the initial plan in a way that leaves the available alternative plans able to recoup only some lower value. Williamson further explains that times like this are unfortunately when opportunism can take hold; where he defines opportunism as "[s]elf-interest seeking with guile, [including] calculated efforts to mislead, deceive, obfuscate, and otherwise confuse." ${ }^{, 10}$ Returning to our tropical story, this would mean that the initial or subsequent buyers misleadingly proclaim an inability to buy the produce hoping secretly to settle on a lower price: "I can't pay full price because my banana shelves collapsed and I can't rebuild them fast enough without using the cash I now have on hand," while knowing a cheap and easy repair will be sufficient; or "my rum factory has one extra but older machine that costs far more to operate," while knowing the newer machines have excess capacity available at lower cost. Although little actual harm may come from either party having merely its side of the holdup problem, asset specificity on the one hand and opportunism on the other, the confluence of the two is what causes the serious problem of holdup. That is, the key to Williamson's well-accepted definitions is that the perpetrator is acting badly by misleading, obfuscating, and so forth, and the victim is unable to self-protect, having been caught at the last minute without attractive available substitutes and unaware of the full and true set of facts. ${ }^{11}$

Holdup problems are sufficiently common across human history that a vast literature has been devoted to better understanding why these problems have not blocked economic activity altogether and how we can avoid them going forward. A brief review of the lessons learned from the extensive and diverse literature helps focus the thinking about the way the risk of holdup is most likely playing out within the particular context of patent remedies.

Those studying the boundaries of business firms have explored the ways in which vertical integration can bring together, aligned within one enterprise, two or more smaller enterprises that might otherwise clash with each other across a holdup problem. In the case of our tropical story that would mean, for example, bringing within one business enterprise the harvesting of sugar cane and the manufacturing of rum or sugar, or the harvesting of bananas and their shipping to grocery stores in the United States. ${ }^{12}$ In the case of a more recently studied controversy, it might mean bringing the Fisher Body business of making car parts like body panels within the General Motors business of making entire cars. ${ }^{13}$

${ }^{10}$ Oliver E. Williamson, The Mechanisms of Governance 378 (Oxford Univ. Press 1996) [hereinafter Mechanisms OF GOVERNANCE]; see also Williamson, supra note 9, at 47-52, 64-67 (detailing different forms of opportunism).

${ }_{11}^{11}$ Epstein, Kieff \& Spulber, supra note 1, at 16.

12 Stephen H. Haber \& Victor A. Menaldo, Rainfall, Human Capital, and Democracy 21 (2011), available at http://ssrn.com/abstract=1667332 (citing as classic cases bananas (STACY MAY \& GALO PLAZA, THE UNITED FRUIT COMPANY IN LATIN AMERICA (National Planning Association 1958)) and sugar (Hans Binswanger \& Mark Rosenzweig, Behavioral and Material Determinants of Production Relations in Agriculture, 22 J. DEV. STUD. 503-39 (1986); ALAN Dye, Cuban Sugar in the Age of Mass Production: Technology and the Economics of the Sugar Central, 1899-1929 (Stanford Univ. Press 1998))).

13 While the GM-Fisher Body story is often cited as the canonical example of vertical integration needed to avoid holdup, that view of the story has been proven to be factually inaccurate. See Ronald Coase, The Conduct of Economics: The Example of Fisher Body and General Motors, 15 J. ECON. \& MGMT. STRATEGY 255 (2006). See also Ramon CasadesusMasanell \& Daniel F. Spulber, The Fable of Fisher Body, 43 J.L. \& ECON. 67 (2000). Holdup may even have been exacerbated by the integration of these two firms. As explained by Freeland,

[t]he GM-Fisher case is ... the most widely cited example of vertical integration reducing problems of physical and human asset specificity, and it serves as an empirical cornerstone for hold-up explanations of unified ownership .... [But] while holdup was not an issue prior to integration, the Fisher brothers successfully held up 
A need to vertically integrate to avoid the holdup associated with certain types of assets has been shown by Haber and Menaldo to have social, political, and economic repercussions that may be sufficiently significant to determine whether societies walk a path towards democracy or autocracy. ${ }^{14}$ Haber and Menaldo show how moderate rainfall in certain regions of the world has allowed for the production of crops that happen to be easily storable and exhibit modest economies of scale, which leads to the efficient unit of production being the family farm, which in turn incentivizes broad intergenerational investment in human capital that increases the chance of democratic political governance. ${ }^{15} \mathrm{~A}$ key difference they highlight in the holdup potential of assets like bananas and sugar cane on the one hand and grains and legumes on the other hand is the asset's degree of storability, which allows it to be redeployed to other uses or users if particular plans are frustrated. ${ }^{16}$

While shifts in technology-like the advent of refrigerated shipping in the case of bananas ${ }^{17}$ - may decrease the holdup potential for some assets, other assets are inherently less likely to trigger holdup risk at the outset because they already have characteristics that preserve their value longer, at least long enough to allow the pressure of sharp bargaining by the opportunistic to cut less harshly into the reasonable investment-backed expectations of the potential holdup victim. For legumes and grains, that characteristic is innate storability, which gives each harvester time to find alternative customers and each customer time to find alternative sources.

For patents, the analogous characteristic is the extent to which the term of their legal enforceability is likely to extend beyond any particular business or legal spat. If patent owners know their patents will remain in force and sustain demand beyond the time it takes to sort out interactions with a potential infringer, then at least the patentees are less subject to some forms of holdup. $^{18}$

Of course, the patent holder represents just one side of the two-sided negotiation. As such, the patent holders' own relief from holdup tells us nothing of its propensity to engage in holdup of its own, against potential users of the patented technology - the issue that motivates patent critics. And this type of holdup, by patentees against alleged infringers, must not be overlooked because

GM after they became employees; far from reducing opportunistic behavior, vertical integration increased GM's vulnerability to rent-seeking behavior.

See Robert F. Freeland, Creating Holdup Through Vertical Integration: Fisher Body Revisited, 43 J.L. \& ECON. 33 (2000).

14 Haber \& Menaldo, supra note 12.

${ }_{15} I d$.

${ }^{16} I d$. at 3 (" $[\mathrm{I}] \mathrm{t}$ [is], of course, possible to grow food [in the tropics]—but what [can] be [grown either has] very low degrees of storability [(e.g. tree crops, such as bananas) or is characterized by extremely large scale economies in production (e.g. sugar cane).]"). Indeed, the vertical integration component of the large-scale economies in production of sugar cane may itself be caused by the degree of storability and the resulting need to avoid holdup.

${ }^{17}$ Robert A. Read, The Banana Industry: Oligopoly and Barriers to Entry, in 10 TRANSNATIONAL CORPORATIONS AND THE EXPLOITATION OF NATURAL RESOURCES 198 (Routledge 1993).

${ }^{18}$ Patentees may still be subject to other patent holdup risks-sometimes called "reverse patent holdup" or a type of "holdout"- within a standard setting organization (SSO), if manufacturers hold themselves out of concluding deals with patentees while demanding that these innovators, who have already sunk the costs of inventing and patenting their technology for use in a standard, offer low royalty terms as a condition for supporting inclusion of that patented technology in the standard. By holding out for unreasonable deal terms, these potential infringers can cause a holdup problem in the opposite direction: against the patentees and all those who have invested in the patentee, like other licensees. Epstein, Kieff, \& Spulber, supra note 1, at 22-23. See also Anne Layne-Farrar, Gerard Llobet \& A. Jorge Padilla, Preventing Patent Holdup: An Economic Assessment of Ex Ante Licensing Negotiations in Standard Setting, 37 AIPLA Q. J. 445 (2009) (explaining how a standard setting organization's [SSO] voting rules can grant licensees bargaining power that can lead to holdup of patent holders). Because the party causing this type of holdup is the one who is a potential licensee of the patent, this sub-category of holdup might also be called "licensee holdup." 
avoiding the risk of it has been the stated focus of nearly all of the recent high profile government actions in the field of patents. ${ }^{19}$

But the general non-patent literature has long taught that holdup problems facing both sides of potential transactions are significantly diminished to the extent the laws, rules, and norms governing the economic system recognize and enforce property rights in the underlying assets and contracts between or among the various interested parties. ${ }^{20}$ This is because predictable and knowable property rights and contracts enable precisely the type of individualized and coordinated planning that makes it hard for a potential victim of holdup to end up surprised and unaware. Returning to the example of cars, suppliers of body panels and manufacturers of cars use a host of planning techniques to avoid holdup, including contracts, cross-investing, and long-term relationships. ${ }^{21}$ As explored in more detail below, in Part 0 , the patent system has evolved a host of such mitigating doctrines of its own, which already are operating independent of the patent remedy doctrines that are current targets for reform debates.

In addition, the general literature also has long taught that informal interactions like repeat play can mitigate holdup risk to a significant degree. Once patentees know they can think long term about how their assets may be used, they and their potential customers both have different incentives. To the extent each expects to engage the other in repeat play, each has incentives to cooperate over the long term. A decision to be opportunistic early on in a business relationship can significantly increase the chance others will respond opportunistically in return later in the relationship, or can at least reduce the odds that the targets of the opportunistic actions will become meaningful business partners, which in turn can drive up the original opportunist's own costs of doing business. Envisioning this chain of events from the start reduces both parties' incentives to act opportunistically in the first instance. Even before directly interacting, incentives to cooperate can be enhanced if market participants generally are able to learn of each others' reputations with respect to interaction with third parties.

Lastly, the general literature also has long taught us to be vigilant about a very different form of holdup than the one that can arise when market actors interact with each other: that is the problem of government holdup, which can arise when market actors have to interact with the government. ${ }^{22}$ Legal entitlements turn out to be most vulnerable to holdup by government, and those most able to influence government, when the entitlements are structured so that their owners and users must directly involve government officials and organizations in order to transact over the entitlements, such as by license, sale, bundling, division, or even seemingly simple pricing. ${ }^{23}$

The more that legal decision-making turns on the flexible discretion of legislators, regulators, and judges, the more it will tend to favor the powerful political constituents who have the ability to most easily influence these government actors, thereby tending to decrease market competition. ${ }^{24}$ The underlying mechanism to envision is not the exchange of some unseemly bag

${ }^{19}$ See supra notes 3-4 and accompanying text.

${ }^{20}$ When ex ante investments can be contracted over, the holdup problem has been shown to vanish. See Vincent P. Crawford, Long-Term Relationships Governed by Short-Term Contracts, 78 AM. ECON. ReV. 485 (1988); Drew Fudenberg, Bengt Holmstrom \& Paul Milgrom, Short-Term Contracts and Long-Term Agency Relationships, $51 \mathrm{~J}$. ECON. THEORY 1 (1990); Paul Milgrom \& John Roberts, Bargaining Costs, Influence Costs, and the Organization of Economic Activity, in Persperctives on Positive Political Economy 57 (J. E. Alt \& Kenneth A. Shepsle eds., Cambridge Univ. Press 1990).

${ }^{21}$ Casadesus-Masanell \& Spulber, supra note 13.

${ }^{22}$ Epstein, Kieff \& Spulber, supra note 1.

${ }^{23}$ Stephen H. Haber, F. Scott Kieff \& Troy A. Paredes, On the Importance to Economic Success of Property Rights in Finance and Innovation, 26 WASH. U. J.L. \& POL'Y 215 (2008).

${ }^{24}$ See, e.g., George J. Stigler, The Theory of Economic Regulation, 2 Bell J. Econ. \& MGMT. SCI. 3 (1971) (basic public choice explanation about how concentrated benefits lead to particular government actions); Stephen Haber, Introduction: The Political Economy of Crony Capitalism, in CRONY CAPITALISM AND ECONOMIC GROWTH IN LATIN AMERICA: THEORY AND EVIDENCE xi (Stephen Haber ed., Hoover Inst. Press 2002) (data supporting "crony capitalism" theory of regulation). 
of cash or off-books favor. Instead it is the nature of the extensive communications the government officials would have with those business interests most able to wield political influence. The path is paved with the best of intentions. Every business, large and small, has a legitimate interest in communicating with government officials, including First Amendment rights to Petition the Government and Fifth Amendment Due Process rights to be heard (to varying degrees). And well-intentioned government officials, often more expert in the inner workings of governmental bureaucracy than the workings of the marketplace outside government, want their official actions to be well informed by the expert business and technological information and acumen offered by leaders in the marketplace. But the path takes a pernicious turn when it enters territory that gives these officials the ability to make decisions with increased latitude, discretion, reliance on subjective factors, and deference, decreasingly burdened by requirements for objective facts. Decisions of this type are most vulnerable to favoring those parties best able to wield political influence, which tilts the playing field leading to decreased competition.

Alternative procedures that further insulate officials from influence when wielding enhanced discretion unburdened by detailed factual records have their own serious shortcomings. As elucidated by Elinor Ostrom, who shared the Nobel Prize with Williamson, government shaping of entitlements suffers serious inaccuracies due to officials' limited knowledge of the particular facts on the ground compared to that of the market actors who are more closely involved. ${ }^{25}$ Furthermore, because government officials cannot openly negotiate over their decisions, or credibly commit to being bound to stick to any actions they do take, they are more likely to cause a type of government holdup that is hard to mitigate without completely exiting the system and that is especially susceptible to exacerbation through stacking. ${ }^{26}$

In the context of the present debate about patent remedies, the outline of the government holdup story would run as follows. It could start with increased court or agency review of patent licensing and royalty determinations made by private parties in the marketplace or by fact-finding juries in court cases. For example, one party to a license contract might seek to use the courts or an agency to rewrite that contract, say by nullifying particular terms or conditions that the party agreed to at the time of signing but later regretted. Or a party might attempt to reshape license negotiations through court or agency intervention or its threat. This risk is unfortunately exacerbated by some reform proposals, like those in the FTC Report that would significantly increase the government's discretionary role in setting and maintaining in force the terms in patent licenses. The problem then could be exacerbated by the limited knowledge these government actors have compared to the individual market actors most directly involved. And it could stack, as the Patent Office, the Department of Justice Antitrust Division, the Federal Trade Commission, several influential court judges, and other areas of government each signal that they are receptive to taking actions on this front. This sort of industrial policy, where courts and government agencies intervene in commercial disputes to pick the winners and losers, would distort competition in the marketplace and would alter firm's ex ante incentives to negotiate reasonable solutions in good faith. These would be harmful unintended consequences worth trying to avoid.

\section{NON-REMEDY DOCTRINES IN THE PATENT SYSTEM THAT MITIGATE SIGNIFICANT PATENT HOLDUP RISKS}

${ }^{25}$ See, e.g., Elinor Ostrom, Collective Action and the Evolution of Social Norms, 14 J. ECON. PERSP. 137 (2000).

${ }^{26}$ See F. Scott Kieff, On Coordinating Transactions in Intellectual Property: A Response to Smith's Delineating Entitlements in Information, 117 YALE L.J. POCKET PART 101, 106-09 (2007) (citing Richard. A. Epstein, The Permit Power Meets the Constitution, 81 IOWA L. REV. 407 (1995)) (labeling the problem "permit thickets"); Sunita Parikh \& Barry R. Weingast, A Comparative Theory of Federalism: India, 83 VA. L. REV. 1593, 1608 (1997) (labeling the problem "License Raj”). 
Although the risk of patent holdup by patentees is a problem that can be appropriately addressed by court and agency action, it is less severe than many patent critics postulate because a number of non-remedy doctrines in the patent system succeed in mitigating much of this risk. These doctrines go a significant distance to help ensure that the core definition of holdup, which requires both asset specificity and opportunism, is not triggered. ${ }^{27}$ They greatly facilitate the individualized and coordinated planning that help avoid holdup.

While the substantive laws governing whether a particular technology meets the requirements for a valid patent often are seen as focusing on the merits of a given patent applicant's claim to have made a good invention, they turn out to directly address a great deal of the patent holdup risk by helping to seriously decrease the chance that third parties to the patentee might make assetspecific investments that could otherwise become the target of a patentee's opportunistic decision to engage in holdup. Indeed, this patent holdup-mitigating view of the normative basis underlying the rules over the conditions for patentability provides descriptive coherence to a complex body of law that otherwise appears to have evolved haphazardly. ${ }^{28}$ For example, patent law's doctrines relating to the prior art have long helped ensure that valid patent claims do not cover technology in which, or even towards which, potential patent holdup victims are likely to have significantly invested. ${ }^{29}$ Similarly, patent law's doctrines relating to the disclosure that must be provided in a patent helps third parties avoid making reasonable investment backed expectations in the territory that could be targeted for threat of patent holdup by valid patent claims. ${ }^{30}$

This latter point about the role of patent disclosures is especially important because it is inconsistent with the approach taken by recent commentators and policy makers when discussing the crux of their concern about patent holdup. More particularly, the FTC Report relied heavily on the premise that patents fail to give enough notice to allow third parties to avoid asset specificity problems, including the purported need to improve patent notice in its title. ${ }^{31}$ In so doing, the FTC Report built on academic work claiming that a core cause of patent holdup is the inability for its victims to have reasonably avoided being unaware of their trespass into patented territory before making their asset specific investments. ${ }^{32}$ But most of the recent high profile cases so often held out as examples of patent holdup deriving from a lack of patent disclosure or clarity do not support

${ }^{27}$ The set of doctrines explored here does not exhaust the full set currently in use. Others include the availability of compulsory licensing in special cases, as well as a host of other existing "pressure-release valves" operating in the patent system through their role in the larger system of general commercial law, such as the uncertainty and delay of litigation, the use of limited liability business forms like the corporation, and bankruptcy law. See Richard A. Epstein \& F. Scott Kieff, Questioning the Frequency and Wisdom of Compulsory Licensing for Pharmaceutical Patents, 78 U. CHI. L. REV. 71 (2011) (reviewing compulsory licensing); F. Scott Kieff, Removing Property from Intellectual Property and (Intended?) Pernicious Impacts on Innovation and Competition, 19 SuP. CT. ECON. Rev. 11, 31-33 (2011) (reviewing existing set of pressure-release valves from the general body of commercial law).

${ }^{28}$ F. Scott Kieff, The Case for Registering Patents and the Law and Economics of Present Patent-Obtaining Rules, 45 B.C. L. REV. 55 (2003).

${ }^{29} I d$. at 76-99. By relying largely on factual determinations not subject to flexible discretion and administrative deference, these patentability rules long operated with remarkably low administrative, public choice, and both Type I and Type II error costs. See F. Scott Kieff, How Ordinary Judges and Juries Decide the Seemingly Complex Technological Questions of Patentability over the Prior Art, in Perspectives on Properties of the Human GenOme Project 471 (F. Scott Kieff ed., Academic Press 2003). Recent shifts towards administrative approaches to deciding these issues may undermine these salutary features by making them more amenable to flexible administrative discretion and deference, thereby leaving them less effective in mitigating market-based holdup problems as well as more subject to political influence by large, established firms. See F. Scott Kieff, The Case for Preferring Patent Validity Litigation over Second Window Review and Gold-Plated Patents: When One Size Doesn't Fit All, How Could Two Do The Trick?, 157 U. PA. L. Rev. 1937 (2009).

${ }^{30}$ Kieff, supra note 29 , at 99-105.

${ }^{31}$ FTC Report, supra note 4, at 22.

32 See, e.g., James Bessen \& Michael J. Meurer, Patent Failure: How Judges, Bureaucrats, and Lawyers Put INNOVATORS AT RISK 29-72 (Princeton Univ. Press 2008) (cited by FTC Report, supra note 4, at $81 \mathrm{n} .46$, in support of the claim that patents are difficult to interpret "across the board"). 
this claim. ${ }^{33}$ In these cases the patents were adjudicated through extensive litigation to have provided disclosures that were adequate rather than insufficient, to enable anyone of reasonable skill in the particular technological art to which the patent pertains to make themselves fully aware of what the patent covers and what it does not just by reading the published patents themselves.

This does not mean that the socially optimal level of due diligence searching by potential patent infringers would actually turn up every valid patent claim that avoids the prior art and sets forth a legally adequate disclosure. There are surely patents that are not infringed or are invalid, such as those that provide inadequate disclosure, or are valid and infringed but sufficiently far afield that even with diligent good faith searches, locating them is too difficult. Some areas of technology may be more susceptible to these risks than others. ${ }^{34}$ This category of patents could leave manufacturers open to the type of unaware asset specific investment that, if met with opportunism by the patentee, would satisfy the definition of patent holdup.

Note, however, that such risk is further mitigated by a host of informal, voluntary private ordering tools evolved by participants within the patent system. These include reliance on standard setting organizations (SSOs), direct interaction among participants in the marketplace for patented technologies including licensing, general reputation and repeat play, unilateral commitments out to all in the marketplace to offer licenses on reasonable and non-discriminatory (RAND) terms (or even royalty-free), and a general willingness to license rather than litigate. ${ }^{35}$

To be sure, these non-remedy doctrines in patent law combined with the private ordering tools may still not sufficiently mitigate all risk of patent holdup. Manufacturers do face the risk that an appropriate due diligence search may fail to uncover a relevant patent before appropriate asset specific investments are made; and a patentee may then opportunistically engage in patent holdup. This remaining risk is discussed below.

\section{PATENT HOLDUP RISKS IN THE CONTEXT OF PATENT REMEDIES}

As the non-remedy doctrines in patent law do not sufficiently mitigate the risk of patent holdup, those remaining risks generally can be divided into two types. One is a residual risk of patent holdup that the patent remedy doctrines should mitigate. The second is a risk of reverse patent holdup (or licensee holdup) that should at least not be exacerbated by the introduction of new policies targeted too narrowly at patent holdup. Both of these two types of risks can be felt more keenly in the context of standard-setting. But focused attention to the cause of each of these two types of patent holdup risk can help develop reform proposals more tailored to better mitigating those that are significant problems while better avoiding the unintended consequences of causing other significant problems.

${ }^{33}$ Epstein, Kieff \& Spulber, supra note 2, at 24-25 (citing high-profile cases in which large companies RIM, eBay, and Microsoft brought unsuccessful challenges to, inter alia, the disclosures of various patents).

${ }^{34}$ But fitting any particular technology into the proper category can face more than the usual line drawing problems. Taking in the aggregate all of the arguments made about patents brings this point into high relief: high tech products are said to be so componentized that the patent notice problem is so much worse for them (more components equals more targets) that the entire category should be exempt from patents, while low tech products are said to be so simple that the entire category should be treated as per se unpatentable for being obvious, and biomedicine products are said to be so essential that all of their patents merit compulsory license to entities further down the production chain. If each of these arguments is taken for its full effect, the practical business impact of a categorization decision would matter little because any particular patent can be ignored by the market so long as the patent can credibly be labeled as a member of at least one of these categories. Indeed, the effort spent fitting a given technology into the right category may merely distract from the overall combined effect of treating each specific category with enhanced skepticism about patent enforcement.

${ }^{35}$ Epstein, Kieff \& Spulber, supra note 2, at 8-26. 


\section{A. Residual Patent Holdup Risk}

The moment at which the risk of patent holdup often is seen most starkly is when a potential infringer is contemplating the remedies for infringement of some particular patent about which she was unaware when making significant asset specific investments in the activity alleged to be infringing. Much of the literature attributes the blame for this surprise to a characteristic of patent infringement liability that distinguishes it from liability for infringing tangible forms of property. ${ }^{36}$

A typical case of patent infringement is a type of offense that lawyers call "strict liability" because the infringer's intent is usually irrelevant to the question of whether there will be liability, as distinguished from questions about the amount of liability. ${ }^{37}$ Many areas of law operate this way. For example, a person's liability for taking your car exists regardless of whether the taker knew who the proper owner was, with a base level of liability that likely is not much more than an obligation to return the car or an objective measure of its value to the true owner. Enforcement approaches like this are said to be "in rem" ("in the thing"), without regard to the particular in personam characteristics of the taker, such as intent. One benefit of such in rem enforcement rules is that they impose relatively low information costs on all third parties to the asset. The world of non-owners need only know that they are not owners, in order to determine their duties with respect to the thing, which essentially are to leave it alone. They don't have to know who the owner is, or what arrangements the owner or owners may have with each other, such as joint ownership, ownership divided over time as in the case of a life estate followed by a future interest, or some contingent interest like a mortgage. Critics of patent remedies point out that this information cost savings for property rights in land is not available for patents because unlike patents, assets that are tangible, like a car or land, rely on their physicality to accomplish the low search and information costs of in rem enforcement. ${ }^{38}$ After all, it is easier to become aware that you have walked onto land that is not your own than it is to become aware that some third party received a patent on what you are doing.

While patent critics are right that patents lack the same physicality of a car or plot of land, they are wrong to imply that such physicality is required to keep third party information costs to a minimum. Recording and registration systems ${ }^{39}$ have long been successfully used by societies to record a host of intangible property interests, such as easements and mortgages, which like patents are defined using mere abstract words rather than physical markers. The search and other information costs imposed on third parties for these intangible property rights remain sufficiently bearable that they have enjoyed stable persistent use throughout US history and are subject to extensive market transactions in primary as well as secondary and other derivative markets. Furthermore, while entitlements to both the tangible and intangible property rights in physical assets like cars and land are governed by different bodies of law in each state and recorded in repositories spread among a vast number of county and municipal recording offices, using a range of standards for legal language and form, the search and information costs on third parties facing patents are comparatively much lower because patents are centrally filed and searchable online for

${ }^{36}$ See, e.g., Bessen \& Meuer, supra note 33. See also James Bessen, Jennifer Ford \& Michael J. Meuer, The Private and Social Costs of Patent Trolls, 34 Regulation 26 (2011).

${ }^{37}$ To be sure, if the particular claim in the asserted patent is limited by intent, then intent would be part of the basic infringement analysis for that particular claim in the patent. But there is debate about whether such intent limitations are even allowed in patents. Furthermore, indirect and group liability for patent infringement also can require proof of intent, such as intent to induce infringement by another or intent to form a legally recognizable partnership with another.

${ }^{38}$ Benito Arruñada, Property as an Economic Concept: Reconciling Legal and Economic Conceptions of Property Rights in a Coasean Framework, 59 INT'L REV. ECON. 121 (2012).

${ }^{39}$ In a recording system, all documents of title are filed (usually in copy, not original) in some publicly searchable government repository with no particular administrative review other than perhaps for form and payment of some filing fee to earn recordation. Registration systems involve the added step of purging conflicting entries when new ones are filed. 
free using one set of forms and a single body of case law governs their text. ${ }^{40}$ Simply put, the centralized and standardized publication of patents goes a very long way in addressing the risk that infringers will be caught unaware. ${ }^{41}$

But even search and information costs that have been decreased by centralization and standardization can be a drag on the system. Patent critics point to many examples in which a party considering whether to manufacture a relatively inexpensive consumer product, like a microwave oven or laptop computer that contains hundreds or thousands of components that may be subject to an even larger number of patents, would experience very high costs to search out, carefully read, and receive advice of legal counsel about all of those patents. Without incurring those costs, however, such a manufacturer could make asset specific investments in a factory, and so forth, and then end up infringing some or even several of those patents totally unaware. Such a manufacturer would be at risk of patent holdup if the owners of those patents engaged in opportunism of the type Williamson defined as involving "calculated efforts to mislead, deceive, obfuscate, and otherwise confuse." ${ }^{42}$

One essential precursor to this particular manufacturer's status as a possible victim of patent holdup is the decision to not incur the search costs to make itself fully aware of the patent landscape, thereby preventing the surprise element necessary for any type of holdup. As explored in more depth in other work, concerns about this group can be decreased once its constituent subgroups are explicitly categorized. ${ }^{43}$ Specifically, manufacturers that do not seem to have accounted ex ante for given patented technology can be placed into one of four subgroups, only some of which call for intervention.

The parties within subgroup 1 are not even available for patent holdup because they turn out to be correct in planning not to need the patented technology. They either did not include it in their plans or can remove it at sufficiently low cost because they have made no asset specific investment. In this case, the patent holder has no leverage to extract patent holdup with the threat of a suit.

The parties within subgroup 2 have made asset specific investments thinking they would not be at risk of being frustrated by a patent or patents but were not correct in their plans. Because members of this subgroup were caught unaware having made asset specific investments, they may be at risk for patent holdup, if the patentees they face approach them opportunistically. But this subgroup can be divided into three further bushels according to the level of investment they made into planning around the possibility of third-party patents. From a societal perspective, these firms may have invested too little, just the right amount, or too much in pre-asset-specific investment due diligence. Although the reforms urged by patent critics would eliminate incentives to invest at the socially excessive level, they also would eliminate incentives to invest at the other levels as well, thereby exposing patentees to reverse patent holdup and short-circuiting incentives for private ordering among all participants in the marketplace for patented technologies. The main benefit of the framework we outline in Part 0 , below, is that it targets only the socially excessive patent clearance investments and thereby avoids the other unintended consequences.

${ }^{40}$ Epstein, Kieff \& Spulber, supra note 1, at 24 .

${ }^{41}$ Like the patent system, the trademark system has a similar registration system for marks in use, as well as for marks that someone intends to put to use. In addition, the chance of an alleged infringer being caught unaware with respect to any unregistered marks is mitigated by the trademark system's requirement that any rights in such marks will be contingent upon a showing by the one claiming ownership of the mark that it has been known to a broad base of market participants to have been functioning like a mark. The copyright system also pays similar attention to ensuring infringers are not caught unaware. Copyright registration is required before various forms of enhanced damages are available for infringement; and the underlying case of liability depends on whether there has been some actual copying. Independent origination is a complete defense to a charge of copyright infringement.

${ }^{42}$ Williamson, supra note 10 , at 378.

${ }^{43}$ Epstein, Kieff \& Spulber, supra note 1, at 19. 
The parties within subgroup 3 include those who made unlicensed asset specific investments in technologies that are patented but who were correct in anticipating the patentees will not be opportunistic, perhaps because of other business dealings. Because opportunism is a necessary ingredient to the holdup recipe, this subgroup falls outside of concerns and therefore should not be targeted by remedies for patent holdup.

The parties in subgroup 4 are those whose planning was to succeed in getting courts or government agencies to intervene on their behalf to obtain better patent licensing terms than available through voluntary ex ante negotiation. This group can be thought of opportunistic in their own rights, as they impose the social costs of exposing patentees to reverse patent holdup and short-circuiting incentives for private ordering among all participants in the marketplace for patented technologies.

Under this taxonomy, it is socially beneficial for a party to be in any of the following three subgroups: 1,3 , and the bushel within 2 , who invest in patent clearance activities at a socially optimal level. A party who meets these criteria has not overly invested in clearance costs and has either engaged in voluntary transactions before infringement, doesn't need a patent license, or is able to get one even post-investment at affordable rates from the patentee. Simply put, none of these parties faces patent holdup and so is not a sympathetic target for any policy reforms urged under the name of patent holdup prevention.

But it is socially destructive to encourage parties to be in the bushel of subgroup 2 that invested in patent clearance costs at a socially excessive level. The system should be sympathetic to those infringers who prove they acted in good faith (that is, after a reasonable clearance search) and who made large, irreversible investments in reliance on the well informed view, where if they had known about the patent ex ante they would have had a sufficiently easy time designing around it (the cost of actually obtaining and putting to use a truly available non-infringing substitute was roughly the same) but now, ex post, the large, asset specific sunk cost they made leaves them vulnerable to opportunism by an unscrupulous patentee. ${ }^{44}$ Policies and institutional procedures should be targeted towards decreasing the chance that patent remedies strike these parties too hard, which would provide counterproductive incentives for more parties to fall into the bushel of subgroup 2 that invested in patent clearance costs at a socially excessive level.

\section{B. Reverse Patent Holdup Risk}

It also is socially destructive to encourage parties to be in subgroup 4 (those using the courts or government agencies to better their licensing terms as compared to private negotiation), as some proposals aimed at eliminating patent holdup risks would do. The extent of subgroup 4 erodes the diffuse incentives patents otherwise provide to all those in the market for commercializing patented technologies. ${ }^{45}$ This subgroup is evidence of socially excessive infringement of a type that exposes patentees to reverse patent holdup in that it decreases the incentives of potential contracting parties to coordinate with each other around patents. For example, patentees and putative licensees and other investors will have decreased incentives to make their asset specific investments in the patent ex ante if they expect that some large manufacturer will enjoy favorable remedies by showing up later uninvited.

\footnotetext{
44 Vincenzo Denicolò, Damien Geradin, Anne Layne-Farrar \& A. Jorge Padilla, Revisiting Injunctive Relief: Interpreting eBay in High-Tech Industries with Non-Practicing Patent Holders, 4 J. COMPETITION L. \& ECON. 571 (2008).

${ }^{45}$ See, e.g., Layne-Farrar, Llobet \& Padilla, supra note 1 (demonstrating how one restrictive licensing cap proposed to address patent holdup of licensees within SSOs would actually lead to lower SSO participation, reduced R\&D investment, and increased patent holdup).
} 


\section{Special Risks of the Standard Setting Context}

The above points hold for patents in general, and indeed for all intellectual property, but an important wrinkle is introduced by patents within the SSO context. In particular, the standard setting process can exacerbate problems of both patent holdup and reverse patent holdup (that is, holdup by patent holders of licensees and holdup by licensees of patent holders).

When firms cooperate to define the interoperability rules for various components and products - such as with mobile phones- the "essential" nature of certain patented technology for compliance with the defined standard can "lock in" manufacturers and patentees, creating a circumstance ripe for opportunistic behavior. More specifically, technologies (many of which will be patented) may compete with one another while the SSO members consider the options for the best standard, but once the standard is chosen this competition ceases, by design. After the standard is defined, then, members may no longer have any viable substitutes to the patents. ${ }^{46}$ As a result, "lock in" is indeed a possibility. However, such standards are publicly known and typically have explicit intellectual property policies, thus the manufacturers cannot fairly be said to have been unaware of potentially relevant intellectual property rights, which is one of the necessary precursors to patent holdup.

In fact, most SSOs provide a number of information elements that work to limit the possibility of patent holdup. First, SSOs typically have rosters of active members, so that the universe of potential patent holders is largely known. Second, most request IPR disclosures of any patents that might be or become "essential" to the practice of the standard. ${ }^{47}$ Even when these disclosures are not precise (as so-called blanket disclosures do not list specific patents but rather make general commitments to license any relevant patents held by the disclosing party on Reasonable and NonDiscriminatory-RAND - terms), the general disclosure record puts on notice any firm wishing to implement the standard - that firm can then conduct patent searches for the firm making the general disclosure. Third, most SSOs have licensing policies aimed at reducing ex post patent holdup, such as requesting RAND licensing, or less commonly requiring royalty-free licensing. ${ }^{48}$

Many have complained that RAND commitments provide little relief for patent holdup problems because they are ill-defined ${ }^{49}$ While it is true that no SSO, to our knowledge, actually defines what "reasonable and non-discriminatory" licensing actually means in practice, there is consensus that at a minimum a RAND commitment ensures good faith efforts at licensing, such that a patent holder cannot refuse to license a willing licensee (outright or constructively) or license exclusively - rights the patent holder would otherwise have. Giving up these rights has a meaningful impact on licensing negotiations: a patent holder within an SSO no longer has as a

${ }^{46}$ Note that this is not as straightforward as it might at first seem. Even patent claims that appear to exactly reflect the technical specifications drafted for a given standard may nonetheless have workable non-infringing substitutes, such as when the courts take a restrictive interpretation of the patent's claims or when the feature in the standard is optional.

${ }^{47}$ Some have decried SSO disclosure rules as encouraging "over-disclosure," and indeed many do, in that patent holders make declarations of potentially essential patents. Given that determining genuine essentiality is a difficult, timeconsuming, and subjective task (requiring a legal and technical comparison of patent claims to standard specifications), this may be a preferable approach to the alternative of "under-disclosure," which would enable more opportunistic patent ambush. But a key point to keep in mind is that there are important reasons to think that those industrial actors actually participating in the SSO will be better than government actors in titrating the rules to the best levels. See supra note 25 and accompanying text.

${ }^{48}$ Some SSOs add "Fair" before RAND, asking for a FRAND commitment. RAND and FRAND are generally viewed as equivalent. Only one SSO (VITA), to the best of our knowledge, requires disclosure of maximum terms and conditions before a patented technology will be considered for inclusion in a standard. IEEE has a voluntary licensing terms and conditions disclosure policy, but few members have taken advantage of it.

49 See, e.g., Marc Rysman \& Timothy Simcoe, A NAASTy Alternative to RAND Pricing Commitments (Boston Univ., Dep't of Econ., Working Paper, No 2010-056 2011), available at http://people.bu.edu/tsimcoe/documents/published/NAAST.pdf. 
threat point walking away from negotiations. Knowing this, licensees have increased bargaining leverage.

In the same spirit of mitigating patent holdup on the part of patent holders, SSOs also seek to avoid the problem of reverse patent holdup on the part of licensees by resisting efforts by private parties, as well as courts and government agencies, to force patentees, who have already sunk the costs of inventing and patenting standard-specific technology, to offer low royalty terms as a condition for supporting inclusion of that patented technology in a standard ${ }^{50}$ In that same vein, many SSOs also acknowledge preferences for reciprocity: firms can condition a license to their disclosed potentially essential patents on receiving a license to the counter party's disclosed potentially essential patents. ${ }^{51}$ In general, a careful balance among the needs of all SSO members, patent holders and implementers, is often an explicit goal of SSO intellectual property policies. ${ }^{52}$

The framework outlined below is centered on balancing the legitimate needs and expectations of both patent holders and manufacturers. As such, it mitigates both the risk of patent holdup and of reverse patent holdup.

\section{CONTRASTING FRAMEWORKS FOR MITIGATING PATENT HOLDUP RISK}

The market and institutional features discussed above play an important role in mitigating the risk of patent holdup, but even when such mechanisms work well, disputes will be inevitable. In that instance, courts offer a backstop. We therefore conclude our analysis by contrasting the popular framework and our proposed framework for the courts to follow when setting remedies for patent infringement. The goal is to find a workable and balanced approach for further limiting holdup risk, in any form that it might take, with an eye towards both increasing direct, palliative effects as well as limiting harmful unintended consequences.

\section{A. Long-Established Remedies Framework}

Both the popular approach and our proposed approach are largely consistent with most elements of the basic framework for patent remedies that has long been established. This long-established framework basically includes three categories of remedies: those that compensate for past infringement, which essentially boil down to money damages; those that prevent or deter future infringement, which essentially boil down to injunctions; and those that are designed to repair for and deter acts of willful misbehavior in the marketplace and in court, which essentially boil down to punitive damages and attorney fees.

For injunctions, whether preliminary or permanent, there has long been a four-factor test, which was recently reaffirmed by the Supreme Court's 2006 eBay decision, under which a "plaintiff must demonstrate: (1) that it has suffered an irreparable injury; (2) that remedies available at law, such as monetary damages, are inadequate to compensate for that injury; (3) that, considering the balance of hardships between the plaintiff and defendant, a remedy in equity is warranted; and (4) that the public interest would not be disserved by a permanent injunction." ${ }^{, 53}$

${ }^{50}$ Epstein, Kieff \& Spulber, supra note 1, at 22-23.

${ }^{51}$ See, e.g., ETSI Rules of Procedure, Annex 6: ETSI IPR Policy $\S 6.1$ (Nov. 30, 2011), available at http://www.etsi.org/images/etsi_ipr-policy.pdf ("The above undertaking may be made subject to the condition that those who seek licenses agree to reciprocate.") [hereinafter ETSI IPR Policy].

52 Karsten Meinhold, Chairman, ETSI IPR Special Comm., The ETSI IPR Policy: A Key Element for the Success of ETSI's Globally-Applicable Standards, EC Workshop on "Intellectual Property Rights in ICT Standardization" (Nov. 19, 2008).

53 eBay Inc. v. MercExchange, L.L.C., 547 U.S. 388 (2006). Significant debate exists about the extent to which this fourfactor test was as well established as the Supreme Court stated. See John M. Golden, Principles for Patent Remedies, 88 
The key is that these four factors are not to be taken together into some sort of all-thingsconsidered-balance; instead they are to be seen as individual narrow categories of special exception to the general rule that an injunction will issue when the patent has been shown to be infringed and not invalid. ${ }^{54}$ For example, the third factor would only be triggered in the case of a grossly disproportionate hardship on the defendant, not merely more harm than suffered by the patentee.$^{55}$ Similarly, the fourth factor, public interest, is centered on concerns about truly serious threats to public health. ${ }^{56}$

The approach to damages has similarly had its own set of four long accepted principles. The first principle acknowledges that while the patentee should not be able to directly go after the infringer's profits, ${ }^{57}$ the infringer's profits may be at least relevant to a damages calculation ${ }^{58}$ so as to give at least some force to the most famous of equitable maxims: "No one shall be permitted to profit by his own fraud, or to take advantage of his own wrong, or to found any claim upon his own iniquity. ${ }^{, 59}$ The second principle allows the patentee to recoup its own lost profits if it can show that the infringer's customers would have bought (or licensed) from the patentee, instead of from some truly available non-infringing substitute that was roughly the same as the patented technology, and that the patentee would have made those sales at a profit. ${ }^{60}$ The third principle ensures that at least some damages will be paid by explicitly stating in the statute that patent damages should be no less than a reasonable royalty. ${ }^{61}$ And the fourth principle allows for either side in a dispute to receive punitive damages and reimbursement for attorney's fees if the other side is proven to have engaged in willful misbehavior in the marketplace or court. The first three of these principles target what is known as "ordinary damages," and the fourth targets what is known as "enhanced damages."

The key point of departure between the popular approach to reform and our suggested approach is the set of presumptions, burdens, and procedures to be applied to these longestablished rules. At a basic level, the currently popular approach has been to take almost any opportunity to tilt the playing field towards infringers and away from patentees, with laser-like focus on mitigating the risk that infringers will be subject to patent holdup by patentees. Our suggested approach is designed to tailor the rules to primarily help only the specific subgroup of actors who have proven behaviors that would make them victims of true patent holdup, as described above. It has the secondary benefit of mitigating the risk facing the specific subgroup of actors who have sound reasons for thinking they are at risk of becoming victims of holdup and so face the dilemma of having to invest sunk costs in asset specific investments or socially excessive costs in patent clearance. It also has the tertiary benefit of not causing the unintended consequences we outlined earlier of approaches that unduly tilt the playing field in favor of the

TEX. L. REv. 505 (2010); Doug Rendleman, The Trial Judge's Equitable Discretion Following eBay v. MercExchange, 27 REV. LiTIG. 63, 76 (2007) ("Remedies specialists had never heard of [eBay's] four-point test.").

${ }^{54}$ F. Scott Kieff \& Henry E. Smith, How Not to Invent a Patent Crisis, in REacting to the SPending Spree: Policy ChANGeS We CAN AFFord 55 (Terry Anderson \& Richard Sousa eds., Hoover Inst. Press 2009).

${ }_{55}$ Richard A. Epstein, A Clear View of The Cathedral: The Dominance of Property Rules, 106 Yale L.J. 2091, 2102 (1997); Herbert F. Schwartz, Injunctive Relief in Patent Infringement Suits, 112 U. PA. L. REV. 1025, 1045-46 (1964); 42 AM. JUR. 2D Injunctions (2005).

${ }^{56}$ See, e.g., City of Milwaukee v. Activated Sludge, Inc., 69 F.2d 577 (7th Cir. 1934) (dissolving an injunction against an infringing sewage-disposal system). While the geography of the line-drawing this factor does around public health may be hard to locate with precision, it is hard to imagine it being so expansive as to include the attenuated and indirect threat of slightly increased production costs for cell phones, laptop computers, television, and games.

57 See Aro Mfg. Co. v. Convertible Top Replacement Co., 377 U.S. 476, 505-07 (1964) (interpreting the Act of $1946 \S \S$ $67 \& 70)$.

${ }^{58}$ See Kori Corp. v. Wilco Marsh Buggies \& Draglines, Inc., 761 F.2d 649, 653-56 (Fed. Cir. 1985).

${ }^{59}$ Riggs v. Palmer, 115 N.Y. 506, 511, 22 N.E. 188 (1889).

${ }^{60}$ Panduit Corp. v. Stahlin Bros. Fibre Works, Inc., 575 F.2d 1152, 1156 (6th Cir. 1978).

${ }^{61}$ Siemens Medical Solutions USA, Inc. v. Saint-Gobain Ceramics \& Plastics, Inc. 637 F.3d 1269, 1290 (Fed. Cir. 2011) ("the floor for a damage award is no less than a reasonable royalty"). 
class of all infringers, which is the significant risk and actual realization of both reverse-patent holdup against the class of all patentees and all their contracting parties as well as the anticompetitive coalitions that the general political science literature teaches can all too easily form, with the end result being government holdup.

To be sure, the approach we take in highlighting these subgroups may draw the types of questions and criticisms generally raised whenever a broad category is subdivided. Some may wonder how well courts, agencies, or legislators may be expected to correctly identify the particular subgroup applicable to a given case, the boundaries among the subgroups, and how mutually exclusive and exhaustive they are. But we see these as features of our approach rather than flaws because our general approach uses the insight about the mere existence of these subgroups to inform approaches that will constructively engage their existence without having to make any of the particular determinations just mentioned. Put differently, all of these questions or criticisms would be serious detractions from our proposal if it hinged on addressing any of them; but because it does not, they are inapposite. In contrast, the highlighting of these subgroups reveals a host of shortcomings in more popular approaches.

At bottom, we think that popular proposals for limiting the risks of patent holdup generally have too myopic a view and thus would likely create more problems than they solve in the end. No remedy will be perfect for all parties at all times - the markets in which patents matter most are large, complex, and diverse - so our concerns are not directed towards any individual proposal in particular. Instead, we are trying to encourage commentators and policy makers to at least consider that in practice among private actors in the marketplace their own needs to balance incentives and effects for all parties means that compromises must be made in order for agreements to be reached. As a result, when courts or agencies come in later to re-write deals that have already been cut and on which reliance has already been made, they can do more harm than good in the name of trying to get the remedy "just right" as viewed narrowly from just one perspective, such as through the lens of licensees worried about potential patent holdup. The goal should instead be to lay the ground rules in a way that first encourages the parties to "do the right thing" from the start and which leaves open the possibility for welfare-enhancing renegotiations when such ex ante agreements do not work out.

\section{B. Popular Reform Approach}

Recent years have seen many proposals for "fixing" the purported problem of patent holdup, and many of these have been implemented through recent legislative and judicial actions. ${ }^{62}$ Unsatisfied with these measures, those who believe the U.S. patent system has reached and remains at the crisis stage seek yet additional changes to many of the long established patent remedy doctrines. They target injunctions, ordinary damages, and enhanced damages.

Two proposals relating to injunctions are focused on patents declared as "essential" to standard setting organizations (referred to as "standard essential patents" or SEPs). Of special note in this category is the debate over whether SEPs, which are bound by RAND commitments, are eligible for injunctive relief. The FTC Report expresses great unease with the use of injunctive relief in patent cases in general, but especially in the particular setting of SSOs. For example, the FTC Report recommends that the case for granting injunctions should be viewed as especially weak whenever the patent is subject to a RAND commitment in the SSO setting. ${ }^{63}$ Recent

\footnotetext{
${ }_{62}$ See Kieff, supra note 27, at 35-41; F. Scott Kieff, Patently Bad Policy, Defining IdEAS, Nov. 16, 2011; F. Scott Kieff, File First, Invent Later?, DefinIng IDEAS, June 13, 2011; F. Scott Kieff, Patent Reform Goes Haywire, DefinING IDEAS, June 10, 2011; F. Scott Kieff, Welcome to Patent Purgatory, DefinING IDEAS, June 9, 2011; F. Scott Kieff, The Perils of Patent Reform, DEFINING IDEAS, June 7, 2011.

${ }^{63}$ FTC Report, supra note 4, at 28, 234-35.
} 
submissions to the ITC have argued that a RAND commitment outright precludes SEP holders from even seeking an injunction. ${ }^{64}$

The central problem with these proposed reforms is that they would have overly broad application. Categorical rules against the seeking of injunctions for a particular class of patents will not simply prevent ex post patent holdup; it will also tip the ex ante licensing negotiation playing field such that reverse patent holdup, where licensees force below FRAND royalties, is a greater risk. ${ }^{65}$ It also invites increased costs of court or agency review as every infringer is rationally drawn to make decisions about what to invest in litigation as the issue turns on the extent of their own inefficiently sunk costs that are otherwise at stake of being lost through the injunction.

For example, interpreting a RAND commitment as preventing patent holders from ever seeking an injunction would overlook the dynamic impact it would have on incentives for putative licensees to take a license up front. ${ }^{66}$ More specifically, infringers would rationally consider the benefits of simply avoiding any up front offer to take a license on any terms, RAND or not, knowing that on the back end they will not have to face an injunction for any patent that makes its way into any RAND commitment from within an SSO. To avoid this perverse incentive effect, infringers should not be able to avoid an injunction even in a RAND setting unless they can show that they actually made good faith efforts to enter into a license under RAND terms that the patentee had offered or would have accepted with some actual or potential licensee.

It would be an invitation for opportunism by infringers to let the rule be that merely asserting one's own willingness to become a licensee on self-defined terms would allow one to obtain a license on those terms ${ }^{67}$ Infringers could always say they want a license, all the while doing things that they know will slow down or derail the process but which can be justified on some grounds.

It also would be perverse to suggest that a patentee who doesn't offer a RAND license should get potentially higher license rates and more likely access to an injunction. This behavior would place the parties in our subgroup 4, involving some manufacturers using the courts or agencies to obtain better terms and conditions than could be achieved through good faith negotiations, as defined above. Such a rule would incentivize fewer RAND commitments and would also increase

${ }^{64}$ See, e.g., Colleen Chien, Richard J. Gilbert, Carl Shapiro, Thomas F. Cotter \& Stefania Fusco, RAND Patents and Exclusion Orders: Submission of 19 Economics and Law Professors to the International Trade Commission (Santa Clara U. Leg. Stud. Research Paper No. 07-12, 2012). While Google recently committed to antitrust authorities to limit its own ability to enforce those newly acquired patents to the extent they are subject to enforceable commitments to be licensed on fair, reasonable, and non-discriminatory (FRAND) terms, that new commitment does not appear to limit injunctions if the other party does not agree to terms that are FRAND; nor does it reach all of the newly acquired patents or any of the patents within Google's treasure trove of original patents on search. In re Motorola Mobility LLC \& Google Inc., No. 1210120, at 4, 7 (F.T.C. Jan. 3, 2013), available at http://www.ftc.gov/os/caselist/1210120/130103googlemotorolado.pdf (“'FRAND Patent' means a Patent Claim solely to the extent such Patent Claim is subject to a FRAND Commitment. A Patent Claim shall be considered a FRAND Patent only with respect to the practice of such claim implementing the Standard for which the relevant FRAND Commitment was made, and not with respect to the practice of such claim in any other way outside the scope of the relevant FRAND Commitment. . . . Respondents shall cease and desist from directly or indirectly making any future claims for Covered Injunctive Relief based on alleged Infringement of a FRAND Patent except as permitted under this Order. . . . [N]othing in this Order shall . . . require Respondents to give a FRAND Commitment with respect to any Standard or proposed Standard.").

${ }^{65}$ Anne Layne-Farrar, Be My FRAND: Standard Setting and Fair, Reasonable and Non-discriminatory Terms (2010), available at http://www.aipla.org/learningcenter/library/papers/SM/2010-Spring-Meeting-SpeakerMaterials/Documents/ED_2010_SM_Layne-Farrar_PPR.pdf.

${ }^{66} I d$.

${ }^{67}$ For example, in Apple v. Motorola, Apple announced on the eve of trial that it would abide by the judge's RAND determination only if that determination fell below \$1 per device. See Alison Frankel, How Apple Botched Its Fair Rate Case Against Motorola, ThOMSON ReuTERs, Nov. 6, 2012, http://blogs.reuters.com/alison-frankel/2012/11/06/howapple-botched-its-fair-rate-case-against-motorola/; Apple, Inc. v. Motorola, Inc., No. 1:11-cv-08540 (N.D. Ill. June 7, 2012). 
royalty rates and injunction frequencies to levels that are too high, thereby frustrating socially beneficial coordination incentives.

To put the SEP injunction question in the language of the famous four-factor test for injunctions discussed above, the irreparable harm that would be created by following the FTC recommendation for no injunctions on SEPs would derive from encouraging standards implementers to wait-and-see rather than entering into licensing arrangements earlier. That would deprive everyone in the patent marketplace of vital streams of both revenues and technologies. The promise of some money remedy later is cold comfort to all those who suffer the harm caused by preventing such important markets from even coming into existence. The bottom line is that although obtaining injunctions may be rare in the settings of SSOs and RAND commitments, taking them as far off the table as the FTC Proposal envisions would remove from the patentee's toolkit a remedy with a significant value, thereby harming everyone in the market including consumers.

Other proposals target ordinary damages. These proposed changes delve down far into the arcane weeds of the inherently highly speculative process of determining what an alternative universe might have looked like if there had been no infringement. They lead to serious conversations about extreme possibilities that have not been shown to be sufficiently likely to ever exist that they should govern sound policy choices about the rules to use every day in actual cases. For example, one extreme dichotomy that has emerged from one leading commentator views intellectual property rights in brand names like Coke and Pepsi to be so differentiated and powerful that they each cordon off their own monopoly worthy of extensive antitrust regulation, such that an economic market definition exercise would conclude that Coke was not a substitute for Pepsi, and vice versa ${ }^{68}$ At the same time, however, this same commentator argues that for many patents "the patented feature adds no value." ${ }^{\circ 9}$ The reality in many cases surely falls somewhere in the middle, far away from these two extreme poles.

One of these extreme poles is especially hard to imagine as offering practical policy reform guidance. This is the one that views patent infringement as conferring no value on the infringer, sometimes labeled as no marginal value or no incremental value..$^{70}$ Last year, in the Apple v. Motorola case, where Apple's patent on the horizontal swiping motion used with touch screens on cellular phones and handheld computers played a central role, Judge Posner made the substance of his views about patent holdup clear. Specifically, Judge Posner commented on the record that alternative swipes, such as a vertical swipe, were sufficiently acceptable alternatives to the patented invention so as to render the invention "valueless." ${ }^{\text {" } 11}$ In the same dispute, Judge Posner showed deep skepticism about even the possibility of proving any serious value for the design patents on the rectangular shape with rounded edges that often are used as the form factor for smartphones. According to the New York Times columnist Joe Nocera: Posner insists that [patentees] calculate precisely how much the infringing component is driving
demand for the product. For things like rounded corners, it's probably not much. "If they can meet
that challenge, then fine. But it's difficult," [Posner] says. ${ }^{72}$

To the extent Posner's decision to dismiss the Motorola v. Apple case was based entirely on a failure of proof due to the purported failure of the patentees to offer any credible specific evidence

${ }^{68}$ Mark A. Lemley \& Mark P. McKenna, Is Pepsi Really a Substitute for Coke? Market Definition in Antitrust and IP, 100 GEO. L.J. 2055 (2012).

${ }^{69}$ Mark A. Lemley \& Carl Shapiro, Patent Holdup \& Royalty Stacking, 85 TEX. L. REV. 1991, 2002 (2007).

${ }^{70}$ The recognition that true value, marginal value, or incremental value, vary hugely across individuals, and across time reveals a central flaw in the search for these values. See Epstein, Kieff \& Spulber, supra note 1, at 20-21.

${ }_{71}$ Apple, Inc. v. Motorola, Inc., No. 11-cv-8540 (N.D. Ill. Jan. 23, 2012).

72 Joe Nocera, Innovation Nation at War, N.Y. TIMES (Feb. 8, 2013), available at http://www.nytimes.com/2013/02/09/opinion/nocera-innovation-nation-at-war.html. 
of particularized harm, ${ }^{73}$ then it is unremarkable with respect to the question about approaches to patent remedies. But to the extent it reflects a conclusion about the "true" value of the patented technologies or a new approach courts should use in setting such value, the decision overlooks key components of value and distorts the very nature of the valuation exercise.

One key component is the simple evidence that consumers reveal a strong preference for devices having the patented features, whether because of their aesthetic or their function. Consider, for example, the seemingly silly feature of rounded edges for the phones. Entire schools of design thought have competed with each other over the aesthetic value attributable to looks that are overall angular versus overall rounded. ${ }^{74}$ In addition, the choice between angular and rounded brings with it similar tradeoffs in the functional realm. Rounded corners may provide a smoother exterior feel and greater ease when sliding the device into and out of pockets. But rounded corners also leave less room inside the device for important, feature-enhancing electronic components, especially given that dense-packing tends to work best when modular units making up a whole have corners that allow them to be stacked closely together, like lattices in a crystal or bricks in a wall.

At a broader level, a quest for the "true" value of some patented technology, even in the context of a given individual licensee, is misleading. Economic theory on bargaining makes clear that most negotiations have multiple potential outcomes. ${ }^{75}$ This theory is particularly relevant for patent license negotiations, given the subjective nature of the valuation exercise. ${ }^{76} \mathrm{~A}$ single patented technology can offer different licensees dramatically different benefits (value) depending on the use to which the technology is put. Added to this baseline variation are differences in parties' bargaining strength and risk preferences, based partly on each one's other opportunities, which may also vary over time. ${ }^{77}$ Thus, even if the task for a court is to determine a reasonable royalty for a given patent used by a given infringer over a specified period of time, that exercise must make assumptions about the parties' bargaining positions and risk preferences at the assumed hypothetical negotiation date. Each of those assumptions entails some uncertainty; the greater the uncertainty, the wider the range of possible royalty values that can be deemed "reasonable". ${ }^{78}$ Certainly some valuations will have higher probabilities than others, but the point remains that a single "true" value does not exist, at least in any knowable form. This reasoning holds for traditional patent infringement cases as well as for FRAND license disputes. ${ }^{79}$ The latter even add one more layer of uncertainty to the patent valuation exercise: it is not just a question of whether

${ }^{73}$ Opinion \& Order, Apple, Inc. v. Motorola, Inc., No. 11-cv-8540 (N.D. Ill. June 7, 2012) (noting failure of proof).

74 See Keith Lang, Realization of Rounded Rectangles, IU \& US BLOG (July 27, 2009, 8:48 AM), http://www.uiandus.com/blog/2009/7/26/realizations-of-rounded-rectangles.html. See also Anthony Tseng, Why Rounded Corners Are Easier on the Eyes, UX MOVEMENT Blog (Aug. 17, 2011, 10:17 PM), http://uxmovement.com/thinking/why-rounded-corners-are-easier-on-the-eyes/.

75 The seminal work here is by John Nash and is referred to as Nash Bargaining Theory. See John F. Nash, Jr., The Bargaining Problem, 18 ECONOMETRICA 155 (1950).

${ }^{76}$ As Mark Schankerman and Suzanne Scotchmer conclude, "a wide array of damage measures may be consistent with the lost profit (lost royalty) doctrine of damages." See Mark Schankerman \& Suzanne Scotchmer, Damages and Injunctions in Protecting Intellectual Property, 32 RAND J. ECON. 199 (2001).

77 See generally Epstein, Kieff \& Spulber, supra note 1, at 33-40.

${ }^{78}$ Judge Robart recognized that reasonable royalties fall within a range in his groundbreaking ruling in the Microsoft $v$. Motorola decision, the first court ruling on what a FRAND rate is. Findings of Fact and Conclusions of Law, Microsoft Corp. v. Motorola Mobility, Inc., Case No. C10-1823JLR (Apr. 25, 2013) (Robart, J.) (“To decide whether Motorola's opening offers were in good faith, a fact-finder must be able to compare them with a reasonable RAND royalty rate and, because more than one rate could conceivably be RAND, a reasonable RAND royalty range.").

${ }^{79}$ For a discussion of the "range of reasonableness test" for evaluating FRAND offers, see Roger G. Brooks \& Damien Geradin, Taking Contracts Seriously: The Meaning of the Voluntary Commitment to License Essential Patents on "Fair and Reasonable" Terms, in InTEllectual Property AND COMPETITION LAW: NeW Frontiers 389 (Steven Anderman \& Ariel Ezrachi eds., Oxford Univ. Press 2011). 
the SEP is valid and infringed, but also whether it is truly essential for products that comply with the standard. ${ }^{80}$

Most of the proposed reforms are motivated by appropriate skepticism about the weight of the various tiny morsels of evidence and often large inferences a patentee has offered by way of proof in establishing its calculation of a reasonable royalty or damages. As the discussion above makes clear, uncertainties and assumptions are unavoidable in any patent infringement case. But many areas of law are equally messy; the real world is often grey, not black and white. It is in this light that we argue that many of the proposals for patent litigation reform go too far in sweeping off the table entire areas of appropriate analysis, but not far enough in appreciating the high costs to all involved, including courts and agencies, of forcing the patentee to adduce evidence about a decision made long ago inside the secret business workings of the infringer's enterprise to select the infringing technology over any alternatives that may or may not have existed at that time. The infringer is the lowest cost provider of this information, but also the party with the greatest incentives to not accurately maintain it or present it to the court. The infringer also is the one best able to have made the most intelligent decision at the time to balance the costs and benefits of deciding to use the infringing technology, and its sound business judgment should be due some deference when questions are raised about whether the choice of that technology carried any significant benefits. Two conceptual comparisons are especially apt.

First, consider that throughout the law of business associations, including corporations and limited liability companies, the legal doctrine known as the business judgment rule largely prevents third parties from bringing into court any challenges that might question the value of decisions made by a business for having not created value for that business, absent sound reasons for asking whether the decision was invaded by conflict of interest or the product of some fundamentally flawed process ${ }^{81}$ But today's patent critics would go to the opposite end of the spectrum and require third parties and courts to now make precisely such determinations. They would make the third party to the infringer's corporate enterprise - here, the patentee- bear the burden of proving with a high degree of precision, and the court or agency itself determining, the actual amount of the value the infringer obtained for itself by its prior decision to engage in the infringing activity.

Second, consider that patent-critical judges like Posner tend to want to limit socially excessive clearance costs that manufacturers have to spend to avoid patent infringement. This is a laudable goal, but one that has a corollary. Such manufacturer watchdogs should be similarly concerned about socially excessive litigation costs that would ensue if every patentee and every court and agency assessing patent damages had to calculate out to a scientific certainty the precise benefit conferred by this particular infringer's decision to engage in infringement.

The severity of the burden placed on the patentee is particularly striking when one considers the approaches taken to establish patent value. One example of an evidentiary approach already in some use by courts that are skeptical about patent value is to exclude as unduly prejudicial evidence of the value paid to license the patent by other potential infringers in settlements. The idea stems from the realization that because patent rights confer on the patentee no affirmative rights to use the patented technology, and instead only confer the right to sue others to exclude them from the technology, every patent is in that sense a mere ticket to a lawsuit. But because litigation is extremely expensive and uncertain, there is a chance the patent license fees paid by others, perhaps especially in a litigation settlement, reflects merely the value of avoiding the cost

\footnotetext{
${ }^{80}$ Recall that SEPs are merely declared as potentially essential for the practice of a standard. No SSO body makes any attempt to assess whether the patents that are declared as potentially essential actually are essential. Moreover, such a determination can change over time (as recognized in the European Commission's draft Guidelines on Technology Transfer Block Exemption Regulations, latest draft issued February 20, 2013).

${ }^{81}$ See, e.g., Stephen M. Bainbridge, The Business Judgment Rule as Abstention Doctrine, 57 VAND. L. REV. 83 (2004).
} 
and uncertainty of baseless litigation rather than the value of some patented technology. ${ }^{82}$ Many patent critics would not even allow into evidence many measurements of value that other putative infringers placed on the patented technology. Certainly some forms of evidence may be more informative than others (for example, an arms-length license deal versus settlement of a baseless litigation), but hard and fast rules barring one form or another forget that in the real world information of any sort may be difficult to come by and a weakly informative piece of evidence can be better than no evidence at all. And while some settlement values may be more attributable to litigation transaction costs than to technological value, it would throw the baby out with the bathwater to exclude from evidence all valuations reached through settlement of litigation.

Another such proposal would limit royalty rates assessed on the full market price of infringing products save when the evidence establishes that the patented technology is the driver of demand (the Entire Market Value Rule, or EMVR) ${ }^{83}$ The basis of the argument for restrictions on using EMVR as the royalty base rests on multi-component products. When the infringing product has numerous components, such as a laptop, and a particular patented technology reads on but-one of those components (say, video compression software), then payments assessed on the full product run the risk of yielding excessive royalties. As a matter of mathematics, of course, a 1-percent rate assessed on a $\$ 1,000$ product yields the same $\$ 10$ unit royalty payment as a 10 -percent rate on a $\$ 100$ component. That being said, when the $\$ 1,000$ product is likely to be covered by 1,000 patents (has 1,000 plus components), then depending on the value the patented technology contributes to the product, the most appropriate rate might be 0.001 percent, rather than 1 percent. That is the real issue: the rate that best reflects the value of a particular patented technology may be a number that looks "too small", which can pose problems with jury trials.

We recognize the royalty inflation that can occur for multi-component products. It is not that the proposed restrictions on EMVR are ill-founded, but rather that the restrictions are growing broader and broader, drifting farther from their origins in genuinely multi-component product infringements. Court rulings are now arguing that component-based royalties are required for all products, save when the patented technology is the sole driver of demand. ${ }^{84}$ The overly broad application of EMVR restrictions ignores important practicalities and real-world factors, such as the availability of objective pricing for components and the ability of patent holders to monitor component sales to ensure accurate royalty payments. ${ }^{85}$

A similar flaw is inherent in calls to place fixed, binding caps on RAND rates as well. Some of these proposals are wholly unworkable: setting a common 5 percent aggregate royalty cap for SEPs ${ }^{86}$ for instance, irrespective of the end products at issue or the value of the patented technologies at hand, is too far removed from economic theory to be taken seriously. Other proposals properly recognize that RAND rates will vary with the products and patents involved, such as the incremental value rule proposal ${ }^{87}$ Under this proposal, royalty payments would be limited by comparison to the manufacturer's "next best alternative" to the patented technology. However, many incremental value proposals still focus too narrowly on patent-holder holdup, ignoring other forms of holdup. Excessively focusing on the manufacturer's next best alternative

${ }^{82}$ See Layne S. Keele, Res " $Q$ "ing Patent Infringement Damages After ResQNet: The Dangers of Litigation Licenses as Evidence of a Reasonable Royalty, 20 TEX. INTELL. PROP. L.J. 181 (2012) (discussing arguments about excluding from evidence the so-called "litigation licenses" that were explored in the case of ResQNet.com, Inc. v. Lansa, Inc., 594 F.3d 860,872 (Fed. Cir. 2010)) ("license fees negotiated in the face of a threat of high litigation costs may be strongly influenced by a desire to avoid full litigation").

${ }^{83}$ Brian J. Love, Patentee Overcompensation and the Entire Market Value Rule, 60 STAN. L. REV. 263 (2007)

${ }^{84}$ See, e.g., Lucent Technologies Inc. v. Gateway, Inc., 509 F. Supp. 2d 912 (S.D. Cal. 2007).

${ }^{85}$ Damien Geradin \& Anne Layne-Farrar, Patent Value Apportionment Rules for Complex, Multi-Patent Products, 27 SANTA Clara COMPUTER \& High TECH L. J. 763 (2011).

${ }^{86}$ Mark A. Lemley, Ten Things to Do About Patent Holdup of Standards (and One Not to), 48 B. C. L. Rev. 149 (2007).

${ }^{87}$ Jorge L. Contreras, Rethinking RAND: SDO-Based Approaches to Patent Licensing Commitments, ITU Patent Roundtable (Oct. 10 2012). 
would reward the least efficient manufacturers at the expense of both patentees and more efficient manufacturers.

In particular, many incremental value proposals gloss over the baseline value competing technologies offer to a given product and ignore a patent holder's incentives to participate in innovative endeavors. ${ }^{88}$ For example, suppose that patented technology A offers a universal and agreed upon "value" of " 10 " to implementers, while patented technology B offers a universal and agreed upon "value" of " 15 " to implementers. Under the strict interpretations of the incremental value rule, patent holder B would only be able to charge " 5 " for use of its patented technology, as that defines the increment of additional value offered to the implementer. This assumes, however, that competition between patented technologies A and B would push the price of patent A down to " 0 "- an assumption that may or may not be justified in the circumstances at hand. ${ }^{89}$ In short, interpretations of the incremental value rule like this one focus solely on the ex post problem: two (or more) patented technologies already exist (the R\&D that produced them having been sunk and successful) and have no other uses, so manufacturers can exploit both of these facts to push the price of either technology below the value it contributes to the product (" 10 " or " 15 " in the above example). This interpretation of the incremental value rule entirely ignores what economists refer to as the "participation constraint": ${ }^{90}$ if we want innovative firms to make those (soon to be sunk) R\&D investments in the first instance, we need to provide them with an incentive to participate, namely the expectation of an adequate return on investment. Knowing that the return will be restricted to below the value contributed, far fewer innovators will invest in the first place, meaning there may be no competition over technologies at all that manufacturers can then take advantage of to compete down the price of a patented technology. As a result, unless it is very carefully defined and implemented, the incremental value rule would likely cause unintended harmful effects, such as reduced SSO participation and sub-optimal investment in innovation. ${ }^{91}$

\section{Suggested Reform Approach}

Our suggested approach is designed to tailor the rules to primarily help only the specific subgroup of actors who have proven behaviors that make them victims of true patent holdup. Infringers seeking reduced remedies should have to prove that they decided to sink costs in significant asset specific investments in reasonable reliance on having spent efforts in good faith at a level somewhere above a significantly socially suboptimal amount in either clearance costs or in negotiations with the particular patentee, and that the patentee has engaged in opportunism. ${ }^{92}$ These infringers are victims of patent holdup and deserve relief. Patentees should be allowed to rebut this argument with countervailing evidence as well as evidence that they or their contracting parties have made asset specific investments, that the patentee engaged in any licensing discussions in similar good faith, and that the infringer has engaged in opportunism.

First, in litigation the burden should be on the patentee, as it is currently, to prove damages. Patentees can pick the approach that best fits the evidence they can find, either lost profits or reasonable royalties (or mixtures thereof), again as is current practice and as required by statute.

${ }^{88}$ Joseph Farrell, John Hayes, Carl Shapiro \& Theresa Sullivan, Standard Setting, Patents, and Hold-up, 74 ANTITRUST L. J. 603 (2007)

${ }^{89}$ Of course, this example also assumes that a "universal and agreed value" of the patented technologies even exists, which is highly unlikely. Anne Layne-Farrar \& Gerard Llobet, Moving Beyond Simple Examples: Assessing the Incremental Value Rule Within Standards (2013), available at www.cemfi.es/ llobet/multidim2.pdf.

90 JeAn TiRole, THE THEORY OF INDUSTRIAL ORGANIZATION 39 (MIT Press 1988).

${ }^{91}$ Layne-Farrar, Llobet \& Padilla, supra note 1.

92 A related rule of thumb for those cases of infringement that are based on the doctrine of equivalents, which extends the literal claims to cover a penumbra of hard-to-foresee additional invention space, would dictate that the remedy should be presumed (strongly) to include only damages, not an injunction. See Henry E. Smith, Intellectual Property as Property: Delineating Entitlements in Information, 116 YALE L.J. 1742 (2007). 
Patentees of all sorts should be allowed to seek injunctions, and when they are able to satisfy the four factor test, those injunctions should be granted.

But in contrast to the popular reform proposals, our approach would allow the patentee a wider berth with respect to the types of damages evidence that can be used. This recognizes that the task at hand is to offer reasonable chains of inference about a state of the world that is not real and never happened - the but-for world of no infringement-largely involving a decision to infringe that was made by the infringer, a long time ago. So long as the logic is sound the presence of inferential links in the chain should not make it subject to exclusion in its entirety. These inferences should merely go to the weight of the testimony, not its admissibility.

Second, infringers have their opportunity to rebut the evidence presented by the patentee, as is current practice, and like the patentee the infringer should be given a relatively wide berth with respect to admissibility. This means that when a patentee satisfies its burden of proof, the burden shifts to the accused infringer. While theoretical harms like patent holdup or excessive royalties deriving from the application of EMVR may form the basis of a rebuttal, the evidence should be case specific. Theory only goes so far and can apply to either side-it takes facts to properly support a claim. If an infringer can show reasonable clearance costs, that showing should be a big factor in limiting remedies. We do not propose a bright line demarcating the difference between a clearance search that goes too far and one that goes just far enough - the established legal systems of equity and remedies have long recognized that such bright lines have the perverse impact of inviting parties to routinely dance up to and back and forth across them. ${ }^{93}$

Our goal here is to highlight two contrasting concerns the law should be vigilant to address. The first concern is the realization that a manufacturer's good faith clearance search should be respected, and indeed encouraged. This is the nugget of the true patent holdup problem and thus it should be the target of lower remedy approaches. The second concern builds on the views the Supreme Court recently articulated about willful blindness when discussing the standard to be used when determining whether one party actively induced another to infringe a patent. As the Court pointed out, willful blindness exists when two requirements are met: "the defendant must subjectively believe that there is a high probability that a fact exists;" and "the defendant must take deliberate actions to avoid learning of that fact." ${ }^{" 94}$ In that case, the party found to have been willfully blind had specific knowledge of a patent but asked an outside lawyer to conduct a minimal clearance search without informing that lawyer of the same patent. When the lawyer reported back that he found no patents in the way, the party forged ahead and argued later in court when caught for infringement that it lacked a culpable level of intent. The jury, the appellate court, and the Supreme Court disagreed and had little trouble pinning blame on that level of willful blindness.

Third, courts should be mindful of certain arguments to generally avoid and others to be more attentive to. One core element of value that too often is overlooked: option value. ${ }^{95} \mathrm{An}$ infringer benefits from the option to infringe while not paying royalties. Sometimes that infringement will go uncaught, meaning the expected value of knowingly (or with a blind eye toward due diligence) infringing can be positive. And anytime there is infringement the patentee and its contracting parties have lost the option to act exclusively, or to act only under the details of their RAND commitments as opposed to some particular infringer's subject view about what is RAND. The cost of this lost option must be included in any rational damages calculation designed to assess the

93 Henry E. Smith, An Economic Analysis of Law Versus Equity (2010), available at www.law.yale.edu/documents/pdf/LEO/HSmith_LawVersusEquity7.pdf.

${ }^{94}$ Global-Tech Appliances, Inc. v. SEB S.A., 131 S. Ct. 2060, 2070 (2011).

95 Jerry A. Hausman, Gregory K. Leonard \& J. Gregory Sidak, Patent Damages and Real Options: How Judicial Characterization of Non-Infringing Alternatives Reduces Incentives to Innovate, 22 BERKELEY TECH. L.J. 825 (2007); Jerry A. Hausman \& J. Gregory Sidak, A Consumer-Welfare Approach to the Mandatory Unbundling of Telecommunications Networks, 109 YALE L.J. 417, 432 (1999). 
value conveyed to the infringer. Lastly, damages mitigation rules that focus too much on the infringer's costs make no economic sense. In particular, if an infringer claims it could easily work around a patented technology at little to no cost, the court's first question should be whether it did so as soon as the charges were levied against it. If it has not done so, the next question should be why not? In other words, mere assertions of readily available non-infringing substitutes do little to forward the inquiry; evidence is required and actual action and inaction provide meaningful evidence of their own.

We think that if court and agency reviews of damages only keep in mind these basic principles they will go a long way towards strengthening incentives for parties to enter into voluntary exchanges, mitigating the risk of patent holdup in both directions, without placing a thumb on the scales of justice for either side.

\section{CONCLUSION}

Further empirical research may be appropriate to reveal the precise extent and nature of patent holdup due to patent remedies so that additional appropriate private and public steps can be evaluated and taken if warranted. Nevertheless, the expected practical impact of today's popular approaches will be that efforts to evaluate patents, especially in the setting of technological standards, will be subject to increased reliance on the flexible discretion of legislators, regulators, and judges. ${ }^{96}$ The established economics and political science literatures on holdup suggest good reasons to think that the purported patent holdup risk is less severe than popular views suggest and one-sided solutions directed toward patent holdup may cause other, more serious problems, including a tendency to preferentially give more power to large, established companies at the expense of smaller companies, startups, and individual inventors. ${ }^{97}$ A potential consequence may be lower rates of commercializing innovation and higher prices as larger companies no longer feel as much pressure from an already reduced number of new market entrants. Moving in a more balanced approach may mitigate such risks and improve the experience of all players in the marketplace for patents, large and small.

\footnotetext{
${ }^{96}$ Epstein, Kieff \& Spulber, supra note 1, at 2 (noting that while the FTC's proposal does not confer upon that agency any direct power to set the price of patent licenses, if implemented, it would achieve that end).

${ }^{97} I d$. at $31-41$.
} 